\title{
Municipal solid waste management from a systems perspective
}

\author{
O. Eriksson ${ }^{\mathrm{a}, *}$, M. Carlsson Reich ${ }^{\text {b,c }}$, B. Frostell ${ }^{\mathrm{a}}$, A. Björklund ${ }^{\mathrm{a}}$, G. Assefa ${ }^{\mathrm{a}}$, \\ J.-O. Sundqvist ${ }^{\mathrm{b}}$, J. Granath ${ }^{\mathrm{b}}$, A. Baky ${ }^{\mathrm{d}}$, L. Thyselius $^{\mathrm{d}}$ \\ a Department of Industrial Ecology, Kungliga Tekniska Högskolan (KTH), S-100 44 Stockholm, Sweden \\ b Swedish Environmental Research Institute (IVL), P.O. Box 21060, S-100 31 Stockholm, Sweden \\ ${ }^{c}$ Department of Economy, Swedish University for Agricultural Sciences (SLU), P.O. Box 7033, S-750 07 Uppsala, Sweden \\ ${ }^{\mathrm{d}}$ Swedish Institute of Agricultural and Environmental Engineering (JTI), P.O. Box 7033, S-750 07 Uppsala, Sweden
}

\begin{abstract}
Different waste treatment options for municipal solid waste have been studied in a systems analysis. Different combinations of incineration, materials recycling of separated plastic and cardboard containers, and biological treatment (anaerobic digestion and composting) of biodegradable waste, were studied and compared to landfilling. The evaluation covered use of energy resources, environmental impact and financial and environmental costs. In the study, a calculation model (OrwARE) based on methodology from life cycle assessment (LCA) was used. Case studies were performed in three Swedish municipalities: Uppsala, Stockholm, and Älvdalen.

The study shows that reduced landfilling in favour of increased recycling of energy and materials lead to lower environmental impact, lower consumption of energy resources, and lower economic costs. Landfilling of energy-rich waste should be avoided as far as possible, partly because of the negative environmental impacts from landfilling, but mainly because of the low recovery of resources when landfilling.

Differences between materials recycling, nutrient recycling and incineration are small but in general recycling of plastic is somewhat better than incineration and biological treatment somewhat worse.

When planning waste management, it is important to know that the choice of waste treatment method affects processes outside the waste management system, such as generation of district heating, electricity, vehicle fuel, plastic, cardboard, and fertiliser.

(C) 2004 Elsevier Ltd. All rights reserved.
\end{abstract}

Keywords: LCA; LCC; Environmental systems analysis; Waste management; Recycling; Simulation model; Orware; Scenarios; Case study

\section{Introduction}

Due to political decisions, more actions are taken by society towards more sustainable waste management solutions. On the European level, directives on landfilling [1,2] of waste are implemented. As some $15 \%$ of the total municipal waste flow then has to be redirected from landfilling to other treatments, these institutional changes will most probably lead to major changes in Swedish waste management.

In Sweden, producers' responsibility for packages and tires was introduced during the late 1990s [3]. A tax on all landfilled waste was imposed in January

\footnotetext{
* Corresponding author. Tel.: +46-8-790-93-31; fax: +46-8-790-5034.

E-mail address: olae@ket.kth.se (O. Eriksson).
}

2000. In 2002, a ban on landfilling of combustible waste was introduced, and three years later, 2005, organic waste will be included [4]. Today, the capacity to treat this waste does not exist in Sweden, but plans are made mainly for an extension of the incineration capacity. Today, 22 incinerators are in use in Sweden, and another 20 are being planned for [4]. In Sweden, the public opinion concerning incineration is relatively tolerant compared to other European countries. There is however a debate as to whether an increased incineration capacity was the aim of the imposed legislation and suggestions about an incineration tax has been raised [5].

As energy is recovered from waste for use in district heating, the Swedish waste management is also affected by the energy system. The Swedish energy system is bound to gradually change as nuclear power reactors 
are decommissioned in line with a parliamentary decision. Instead renewable energy sources are being introduced on to the energy market, of which waste partly could be seen as one. This means that, besides the regulations in waste management enforcing energy recovery from waste, the need for fuels for generating heat and power will also influence the planning of future waste management.

However, it is not only by incineration that waste can be used for energy recovery. Recycling of nutrients and materials reduces the need for energy intensive extraction and production of these resources, and the biogas obtained from anaerobic digestion can be used as vehicle fuel.

\subsection{Objective}

The aim of the study was to identify the most energy efficient, most cost efficient and least polluting waste management option from a systems perspective.

Other system studies of waste management [6-11] performed in Sweden and abroad have been reviewed. A conclusion from the review is that system studies of municipal solid waste are not as broad as our study and do not have the same kind of scenario construction as made here.

\section{Method}

The study was performed as case studies in three Swedish municipalities. A simulation model of the material and energy flows in waste management based on life cycle assessment (LCA) was used in the quantification of emissions, energy use and financial costs. The model ORWARE (organic waste research) is based on general figures, assumptions and equations and was therefore adapted to each one of the three municipalities. For more information on ORWARE, see for example [12-15].

Eight scenarios comprising different recycling options (Table 1) were set up for each municipality. In this paper, the results from the Stockholm study are presented and the other two case studies are only used for comparison.

Landfilling has often been pointed out as the least favourable treatment method. However, it has been included as a reference scenario in order to emphasize this. Together with incineration, it is the only treatment method that can handle mixed household waste. Apart from these two, recovery of materials (e.g. plastic, glass or metal) and recovery of nutrients (e.g. nitrogen and phosphorus) from organic waste are methods that can be combined with the former mentioned methods landfilling and incineration. For the recycling scenarios, incineration is considered as the only plausible treat- ment method for the unsorted waste. Therefore, the combined effects of materials recycling and landfilling of residual waste have not been studied.

The emissions from the system studied are classified and characterised using methodology from LCA $[16,17]$ into the following environmental impact categories:

- Global warming potential (GWP)

- Acidification potential (AP)

- Eutrophication potential (EP)

- Formation of photochemical oxidants (excluding $\mathrm{NO}_{x}$ )

- $\mathrm{NO}_{x}$-emissions

- Heavy metals (input/output analysis).

In addition to the environmental impact categories above, the consumption of primary energy carriers, the net energy use, and the financial costs for the system are calculated.

The environmental results are also aggregated using monetary weightings for emissions. The monetary weightings are based on willingness-to-pay estimations from [18], except for eutrophicating emission valuations, which are based on [19]. Evaluation of resource use has not been performed in this study.

The financial costs and the aggregated environmental costs are in turn aggregated into welfare economic costs. This aggregation is adjusted for environmental taxes on vehicle fuels (energy taxes on diesel (SEK $0.15 / \mathrm{kWh})$ and petrol $(0.37 / \mathrm{kWh})$ and carbon dioxide taxes on diesel (SEK $0.1523 / \mathrm{kWh}$ ) and petrol (SEK $0.1408 / \mathrm{kWh})$ and landfill tax (SEK $250 /$ ton waste) to avoid double counting.

\section{Model}

In the ORWARE model, the waste management system consists of treatments and transports, according to Fig. 1. In all submodels, the annual turnover (use of) of materials, energy and financial resources in the processes are calculated. Materials turnover is characterised by (1) the supply of waste materials and process chemicals, (2) the output of products and by-products, and (3) emissions to air, water and crops. Energy turnover is the use of different energy carriers such as coal, oil, or biomass, and the recovery of heat, electricity, hydrogen, and biogas from waste. The financial turnover is defined as monetary costs for the processes included.

The materials flow cradle in the model is "waste in bin" from different sources, such as households and industries. Thus, the environmental and economic impact from the waste sources (comprising activities such as cleaning, sorting and transport to recycling 


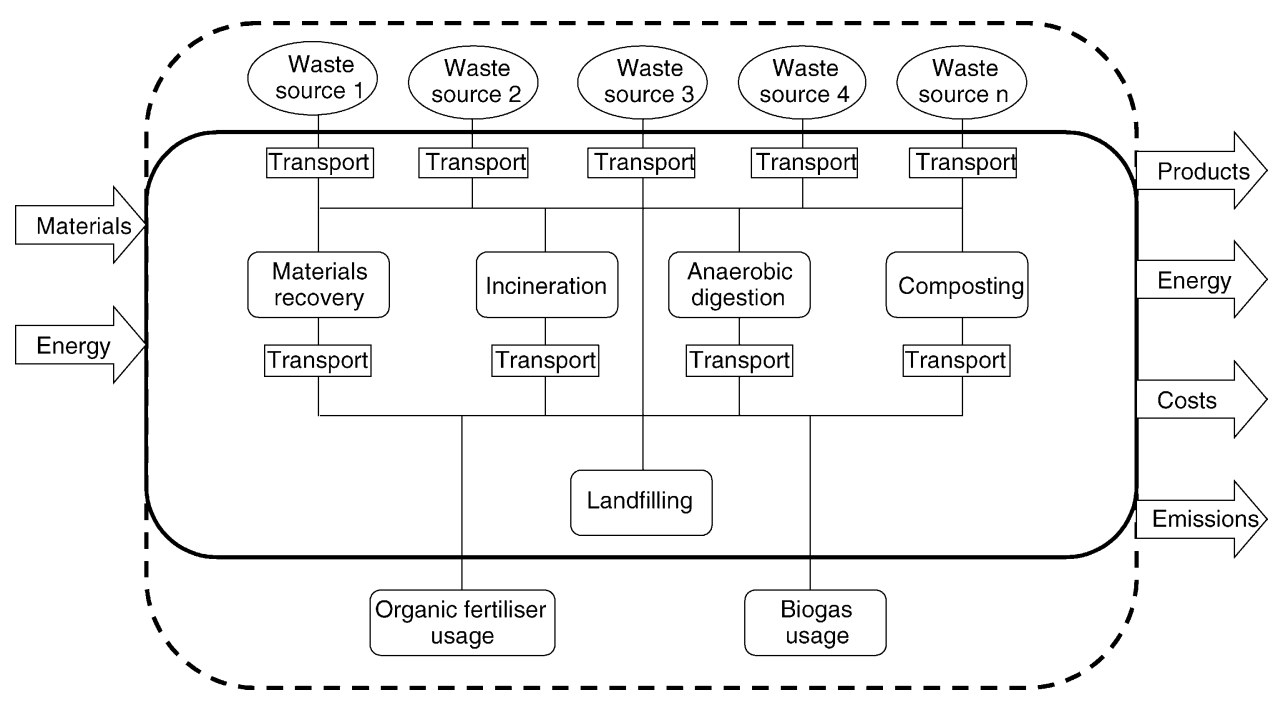

Fig. 1. A conceptual model of material and energy flows in a hypothetic waste management system.

station) is excluded from the system studied. The waste flows are then followed through the waste management system, calculating e.g. changes in composition and emissions depending on the fate of the waste stream. The solid line in Fig. 1 encloses the waste management core system, i.e. where the waste is treated. The dashed line also includes the waste management downstream system, i.e. the use of waste derived products like biogas and sludge as well as the waste sources which are necessary for input of waste to treat even if they are a zero-emission upstream system.

The main function of a waste management system is to treat a certain amount of waste from the system area in a proper way. Today, many waste management systems also provide other functions (benefits) in addition to treatment of the waste, such as recovery of energy and recycling of materials and nutrients. As different waste management systems (or different designs of a planned waste management system in a municipality) can produce different amounts of these functions (e.g. electricity, district heating, vehicle transport, materials and nutrients), comparisons are hard to make. In order to be able to compare, the conventional production (i.e. not derived from the waste management system) of these functions has been added. This makes it possible to level out the output of functions from the waste management system in each scenario, which will give a constant output of the functions for all scenarios. One can say that the conventional system compensates for the waste management system. The above mentioned functions are henceforth called functional units in conformity with the ISO standard, and the system for conventional production of the functional units is hereafter called the compensatory system (see Fig. 2 for an illustration).
The geographical level of application of the model depends on the purpose of the study, but generally it is applied on the municipal level, as that is the administrative basis for waste management in Sweden. The submodels are constructed using either generic data from literature or specific data from the waste management system studied, depending on the availability. As the submodels are modular, they may be combined into the waste management system of, in practice, any city or municipality.

\subsection{System boundaries}

\subsubsection{Functional system boundary}

The functional system boundary in the ORWARE model is treatment of the household-like waste generated within a municipality or a region annually. The system also includes emissions taking place in the extraction of raw materials and generation of energy needed for the waste management (upstream effects, Fig. 2) and the final disposal of the materials used

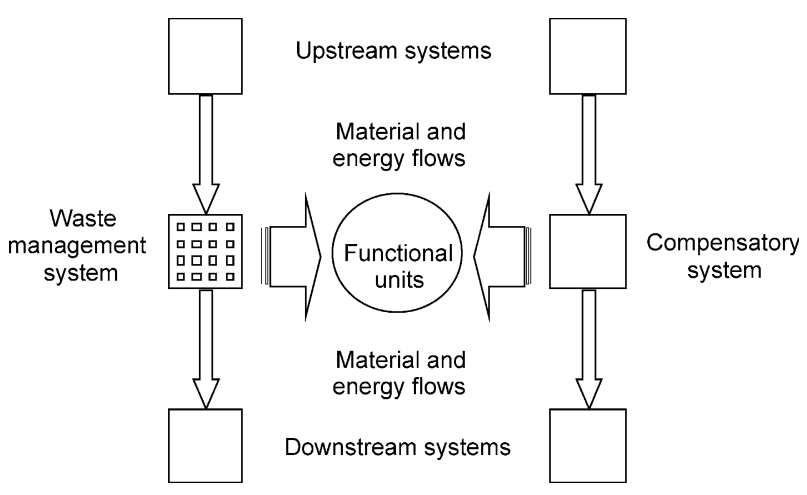

Fig. 2. Conceptual model of the total system in Orware. 
within the system studied (downstream effects, Fig. 2). The compensatory system with its own upstream and downstream effects are also included, Fig. 2.

This system boundary (normally used in LCA studies) was considered more logical than using system boundaries based upon arbitrary locations of treatment facilities, or timing of emissions. This means that not only direct emissions from the waste management are included, but also long-term emissions from landfills (the model calculates the potential emissions for a time period of approximately 100 years which is shown in the diagrams, and also for the remaining time period which is not presented here) and soils used for spreading digestion residue, and the sometimes distant emissions from extraction of raw materials and energy generation.

\subsubsection{Geographical system boundary}

The geographical system boundary was decided to capture the management of mixed household waste and some industrial waste from a certain municipality. Treatment facilities (e.g. recycling of materials) are however not always located within the municipality border.

\subsubsection{Temporal system boundary}

The temporal system boundary covers treatment of and emissions from waste generated during one year.
The emissions from landfill and to some extent soil are emitted over a long time period as described above.

Construction, demolition and final disposal of capital equipment are not included for energy consumption and emissions, as they are normally considered to be a relatively small part of the total emissions of the system [20]. They are however included in the economic calculations, as they are a more important part of the total costs of the system. Thus, the economic calculations could be seen as a life cycle cost (LCC) of waste management.

\section{Scenarios studied}

The scenarios studied are based on four types of waste treatment: incineration with energy recovery (district heating), biological treatment (nutrient recycling and energy recovery), materials recycling, and landfilling with energy recovery (see Table 1 for a closer definition of the Stockholm scenarios). The landfill scenario can be seen as the reference scenario, to which all other scenarios can be compared (as mentioned in the Introduction). Materials recycling and biological treatment should not be seen as competing with each other. They only consider recycling of one specific waste fraction at a time, and it is of course possible to recycle plastic, cardboard and organic waste in parallel.

Table 1

Scenarios studied

\begin{tabular}{|c|c|c|}
\hline Type of treatment & Common features & Scenario short name and specific features \\
\hline Incineration (two scenarios) & $\begin{array}{l}\text { Incineration with heat recovery } \\
\text { and power generation. } \\
\text { Collection and utilisation of } \\
\text { landfill gas in power generation. }\end{array}$ & $\begin{array}{l}\text { IncAll } \\
\text { Incineration of all waste. Energy is recovered as } \\
\text { district heating with a degree of efficiency above } 90 \% \text {. } \\
\text { Inc } 90 \% \\
\text { Incineration of } 90 \% \text { of all waste, } 10 \% \text { is landfilled } \\
\text { during summertime. This is due to maintenance of the } \\
\text { incineration plant and low demand for district heating } \\
\text { leading to partial shutdown of the plant. }\end{array}$ \\
\hline $\begin{array}{l}\text { Incineration }+ \text { biological treatment } \\
\text { (three scenarios) }\end{array}$ & $\begin{array}{l}\text { Source separation of } 70 \% \text { of } \\
\text { the biodegradable waste. } \\
\text { The rest of the waste is incinerated. }\end{array}$ & $\begin{array}{l}\text { BioBus } \\
\text { Anaerobic digestion. Biogas used for fuelling busses. } \\
\text { BioEl } \\
\text { Anaerobic digestion. The biogas is combusted in an } \\
\text { engine for generating heat and power. } \\
\text { BioCar } \\
\text { Anaerobic digestion. Biogas used for fuelling cars. }\end{array}$ \\
\hline $\begin{array}{l}\text { Incineration }+ \text { materials recycling } \\
\text { (two scenarios) }\end{array}$ & $\begin{array}{l}\text { Long distance transport of } \\
\text { recyclable materials to facilities } \\
\text { outside the municipality border. }\end{array}$ & $\begin{array}{l}\text { RecPl } \\
\text { Source separation and material recycling of } 70 \% \text { of HDPE } \\
\text { from households and } 80 \% \text { of HDPE and LDPE from } \\
\text { business. The rest of the waste is incinerated. } \\
\text { RecCb } \\
\text { Source separation and material recycling of } 70 \% \text { of } \\
\text { cardboard from households and } 80 \% \text { of cardboard from } \\
\text { business. The rest of the waste is incinerated. }\end{array}$ \\
\hline Landfilling (one scenario) & $\begin{array}{l}\text { Collection and utilisation of } \\
\text { landfill gas in power generation. }\end{array}$ & $\begin{array}{l}\text { Landf } \\
\text { Landfilling of all waste. }\end{array}$ \\
\hline
\end{tabular}


Recycling of all studied waste fractions at once has not been investigated.

In all scenarios, newspaper (75\%), glass $(70 \%)$ and metal containers $(50 \%)$ are source separated and recycled outside the studied system. The rest is included in the residual waste within the system boundary. Regarding biodegradable waste, plastic containers (high density polyethylene, HDPE) and cardboard containers, a practically feasible upper limit of $70 \%$ source separation in households has been chosen, even though the measured source separation in Sweden only averages some $30 \%$. The high figure is motivated by the method of refining the scenarios to bring out the differences in waste management strategies, aiming at a high degree of source separation in the future if recycling is implemented on a large scale. It is worth mentioning that the goals for materials recycling in Sweden are far below this figure [2]. For companies and industries, 80\% source separation of cardboard and plastic is assumed (the source separated plastic also includes low-density polyethylene, LDPE). We believe that companies that are restricted by environmental management systems will show a higher degree of source separation than private households.

The scenarios studied vary slightly between the three municipalities: composting was not seen as an alternative in Stockholm as in the other two municipalities. The potential use of biogas also differed between the municipalities. In this paper, the scenarios for Stockholm are presented in detail, as most results can be derived from this case study alone. The conditions in the studied municipalities differ mainly as follows:

- Stockholm is a densely populated municipality with an incineration plant and a district heating system. Arable land for spreading of the organic fertiliser is available outside the municipality borders.

- Uppsala is a relatively big municipality, also with an incineration plant and district heating system. Arable land can be found close to the city.
Table 2

Statistical data for the three municipalities

\begin{tabular}{|c|c|c|c|}
\hline Parameter & Stockholm & Uppsala & Älvdalen \\
\hline Number of persons & 496000 & 186000 & 8100 \\
\hline Number of household & s 380000 & 84000 & 5299 \\
\hline $\begin{array}{l}\text { Number of detached } \\
\text { houses in rural areas }\end{array}$ & 0 & 9000 & $\begin{array}{l}\text { North part } \\
2700 \text { p.e. } \\
\text { South part } \\
5400 \text { p.e. }\end{array}$ \\
\hline $\begin{array}{l}\text { Number of detached } \\
\text { houses in city areas }\end{array}$ & 40000 & 19000 & \\
\hline Number of flats & 340000 & 56000 & \\
\hline $\begin{array}{l}\text { Annual tonnes of } \\
\text { biodegradable waste }\end{array}$ & 93121 & 23155 & 1388 \\
\hline $\begin{array}{l}\text { Annual tonnes of } \\
\text { plastic containers }\end{array}$ & 21056 & 2616 & 172 \\
\hline $\begin{array}{l}\text { Annual tonnes of } \\
\text { paper containers }\end{array}$ & 21649 & 3552 & 194 \\
\hline $\begin{array}{l}\text { Annual tonnes } \\
\text { of waste }\end{array}$ & 255100 & 82600 & 2900 \\
\hline
\end{tabular}

- Älvdalen is a small municipality and lacks an incineration plant and district heating system. There is almost no agricultural soil within the municipality borders. As the municipality is sparsely populated, collection of waste is not as efficient as in the other two municipalities.

More specific data for the studied municipalities are displayed in Tables 2 and 3.

\subsection{Assumptions for the compensatory production}

As in many studies where the system has been extended to include a compensatory system, the assumptions for the design of the compensatory system are very important for the results. The assumptions are presented in Table 4.

By far the most important assumption concerning the compensatory system is the fuel type used in heat generation. This is because (1) the environmental

Table 3

Functional units for the three municipalities

\begin{tabular}{lllll}
\hline Functional unit & Unit & Stockholm & Uppsala & Älvdalen \\
\hline Treatment of waste produced & - & Yes & Yes & Yes \\
Electricity & GW h/year & 38 & 13 & $-^{\mathrm{a}}$ \\
District heating & GW h/year & 545 & 212 & 5.5 \\
Cardboard & tonnes/year & 12993 & 2030 & 106 \\
Plastic & tonnes/year & 10318 & 896 & 38 \\
Nitrogen fertiliser & tonnes/year & 247 & 25 & 3.7 \\
Phosphorous fertiliser & tonnes/year & 36 & $5 \times 10^{6}$ & 1.1 \\
Transport by bus & km/year & $16 \times 10^{6}$ & $245 \times 10^{3}$ \\
Transport by car & km/year & $68 \times 10^{6}$ & $-^{\mathrm{a}}$ &
\end{tabular}

\footnotetext{
${ }^{\text {a }}$ Non-existing functional units: no power generation from heat recovery from incineration in Älvdalen, biogas singularly to busses or for heat and power generation in Uppsala and Älvdalen.
} 
Table 4

Compensatory system features

\begin{tabular}{lll}
\hline Functional unit & $\begin{array}{l}\text { Compensatory } \\
\text { production }\end{array}$ & $\begin{array}{l}\text { Sensitivity } \\
\text { analyses }\end{array}$ \\
\hline Electricity & Coal condense power & $\begin{array}{l}\text { Swedish } \\
\text { average } \\
\text { Oil, coal }\end{array}$ \\
$\begin{array}{l}\text { District heating } \\
\text { Cardboard }\end{array}$ & Biofuel CHP & - \\
Virgin, 87\% & \\
Plastic & Virgin, 100\% & - \\
Digestion residue, & replacement & \\
compost & Mineral fertiliser & - \\
Transport by bus & Diesel fuelled busses & - \\
Transport by car & Petrol fuelled cars & - \\
\hline
\end{tabular}

impact from this functional unit is very large compared to the rest of the functional units and (2) the generation of heat within the waste management system varies considerably in the studied scenarios. The choice is motivated by the fact that biofuel is the only fuel that can compete with waste on a financial base.

Many other waste management system analyses also consider "other waste" as a possible alternative fuel in the compensatory system. The choice is supported by the fact that in Sweden there is, and will be for some time, a lack of incineration capacity while combustible waste is being landfilled. However, this study is focused on how to treat waste being landfilled today (scenario Landf), regardless of the present existent facilities. From a waste management planning perspective, the different amounts of waste being incinerated in the scenarios can be seen as different possible sizes of an incineration plant not yet built.
The assumptions for compensatory electricity are based on marginal effects in the power supply system of the Scandinavian countries. Coal condense power from Denmark is the most expensive power supply and is therefore the top load in the power system.

The sensitivity analysis eventually turns the environmental conditions the other way around; Swedish average electricity has low emissions compared to coal condense power and - for district heating — oil and coal are less clean than biofuel.

\section{Results}

Only results for Stockholm are presented, as all three case studies show very similar trends. Differences between the three municipalities are discussed in the next chapter. Bear in mind that the Bio and Rec scenarios consist of a mix of recycling and incineration while Inc and Landf are monotreatment scenarios. Emissions are presented per ton waste treated.

\subsection{Global warming potential}

For the total system (comparing the full bars), as well as for the waste management system (comparing only the white bars), landfilling of all waste contributes most to the GWP of the studied scenarios (Fig. 3). Recycling of materials and nutrients shows slightly lower impact than incineration. Overall changes are small, but the lowest impact is found for recycling of plastic containers.

In all scenarios, the contribution from the compensatory system is larger than for the waste management system. However, in relation to incineration, only the

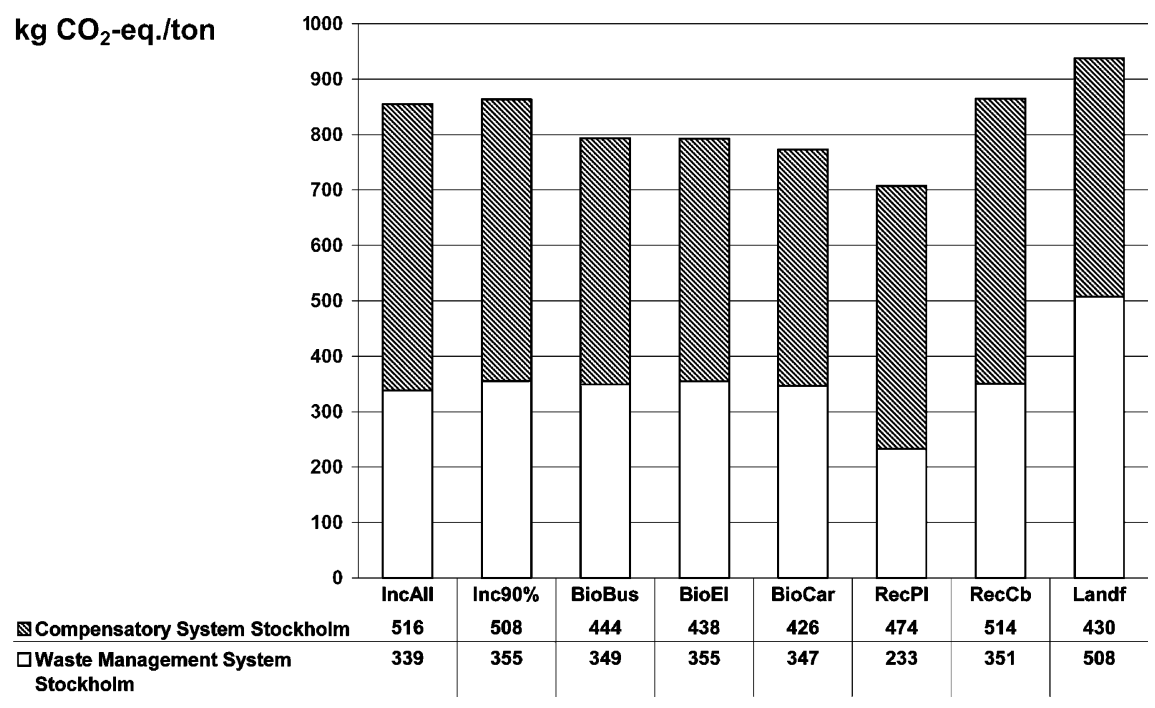

Fig. 3. Global warming potential for the different scenarios. 
Bio scenarios become better as the compensatory system is included.

In all scenarios, except for landfilling, incineration is the main contributor of $\mathrm{CO}_{2}$ emissions emanating from combustion of plastic of different forms. Methane emissions from the landfill have the same effect in the landfill scenario. In the compensatory system, the main contributor in almost all scenarios is external vehicle fuel, i.e. petrol and diesel oil.

The following waste fractions are worth source separating: organic waste, plastic.

\subsection{Acidification potential}

Scenarios BioBus, BioEl and BioCar cause the highest impact for both the waste management system and the total system (Fig. 4). This is due to emissions of ammonia from agricultural soils and for BioEl, high $\mathrm{NO}_{x}$-emissions from the internal combustion engine generating heat and power from biogas. The lowest impact is found for plastic recycling due to lower emissions in combustion of biofuel (compensatory heat) than for production of virgin plastic. All other scenarios are within the same range.

It is worth noting once more that the Bio scenarios become somewhat better compared to incineration as the compensatory system is included.

The main contributor in the waste management system is incineration and in the compensatory system, no major contributor is to be found. They are more or less equal except for biomass combustion which is minor in all scenarios except for the landfilling scenario.

The following waste fraction is worth source separating: plastic.

\subsection{Eutrophication potential}

As for GWP, landfilling has the highest impact due to $\mathrm{NO}_{x}$-emissions from combustion of the landfill gas and emissions of nitrogen, phosphorus and COD (Fig. 5). Recycling of nutrients causes emissions from spreading of the organic fertiliser. These emissions are higher than for spreading of mineral fertiliser. Recycling of materials shows almost the same impact as incineration.

The relation between the scenarios is not changed when the system is extended but the impact in the Bio scenarios become somewhat lower, relatively speaking.

The major source of eutrophication is spreading of the organic fertiliser with emissions of ammonia and nitrate. The biogas engine and the biogas busses are also big polluters producing high emissions of nitrogen oxides. Incineration is the next in order, but is not affected much between the scenarios (except when landfilling). In the compensatory system diesel busses and production of virgin cardboard dominate the emission picture.

The following waste fractions are worth source separating: plastic, cardboard (small difference).

\subsection{Consumption of primary energy carriers}

Observe that this diagram does not show the relation between the waste management system and the compensatory system but the relation between renewable and non-renewable energy resources (Fig. 6).

The differences between the Inc scenarios and the Bio scenarios are small. This is also true compared to recycling of cardboard. The landfill scenario has higher consumption than incineration due to the consumption of biomass for heat generation and recycling of plastic

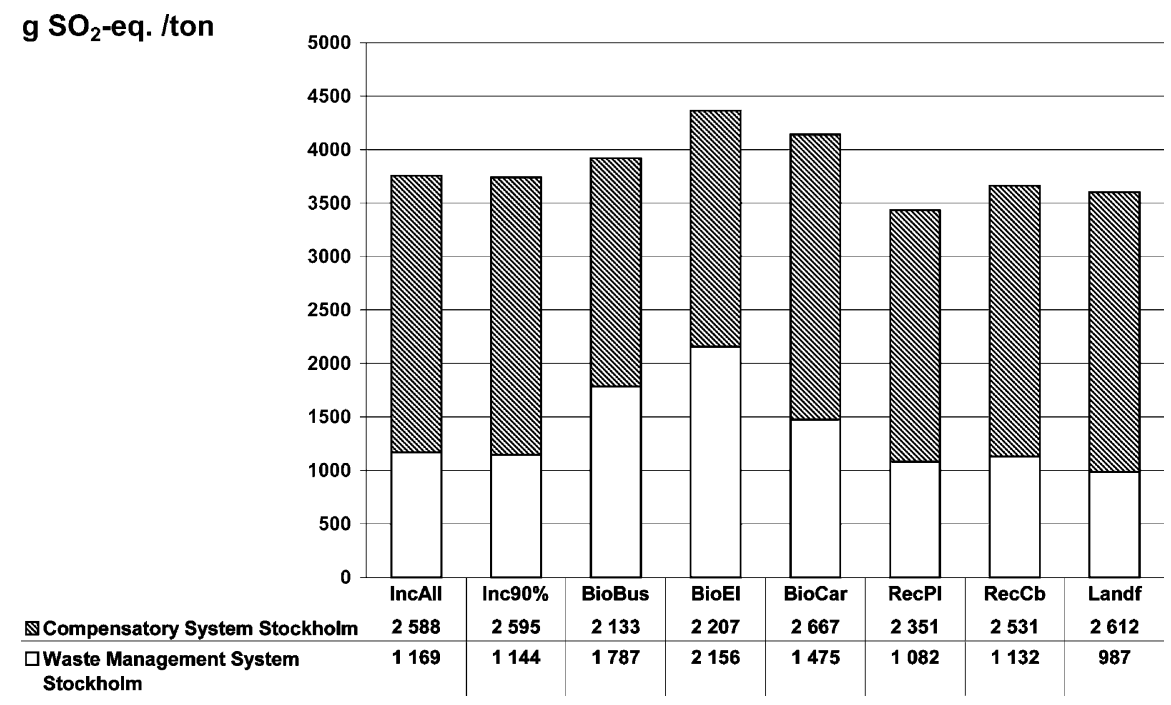

Fig. 4. Acidification potential for the different scenarios. 


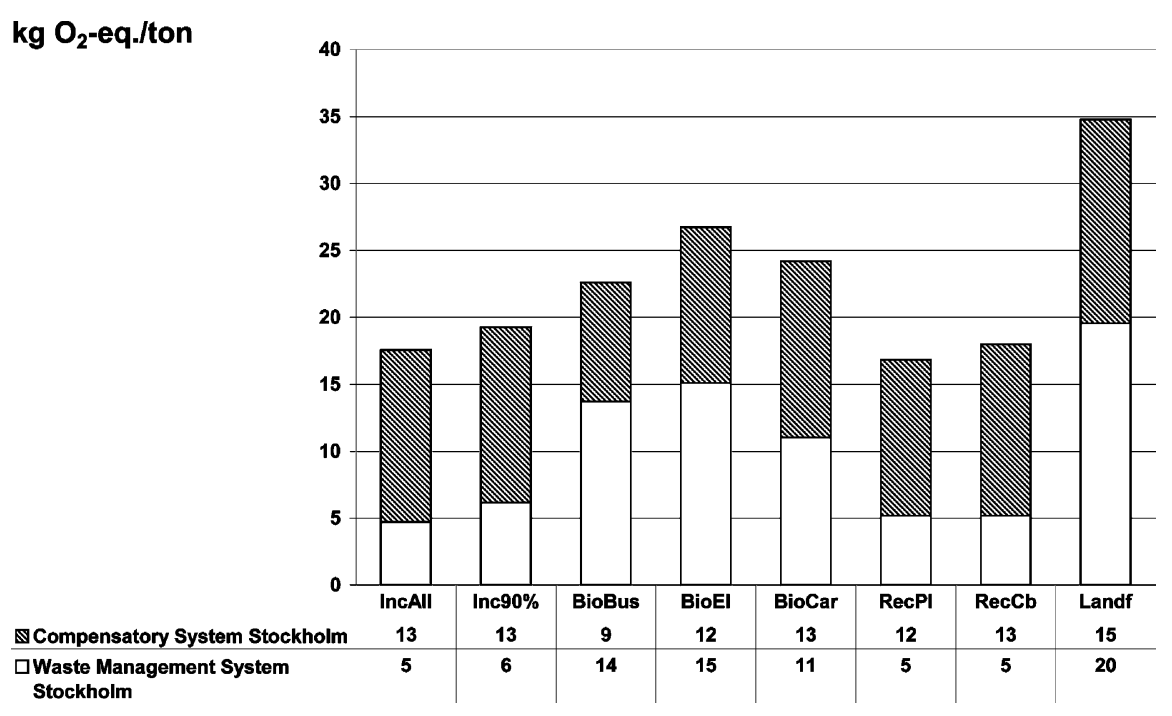

Fig. 5. Eutrophication potential expressed as oxygen demand for the different scenarios.

has lower as consumption of natural gas and oil for production of virgin plastic is avoided. One must however keep in mind that the differences are quite large considering how little waste is being affected in the scenarios.

All scenarios, except the landfill scenario, are dominated by non-renewable energy which consists of diesel oil for collection and transports, coal used for generation of electricity used in the treatment facilities and virgin oil used for producing plastic. Natural gas is consumed in the production of virgin plastic. The renewable part is less in all scenarios except for landfilling when biomass for compensatory heat increases the consumption of energy carriers to become the highest of all scenarios. Besides combustion, biomass is used for producing virgin cardboard and to some extent in upstream processes.

The following waste fraction is worth source separating: plastic.

\subsection{Financial costs}

Unlike the previous diagrams, the impact from the waste management is greater than the compensatory system (Fig. 7). Landfilling is the most expensive waste treatment due to the alternative cost for fulfilling the functional units (mainly heat). The total costs are slightly higher for recycling of plastic compared to incineration, due to the relatively low value of recycled plastics, while the BioCar scenario is marginally

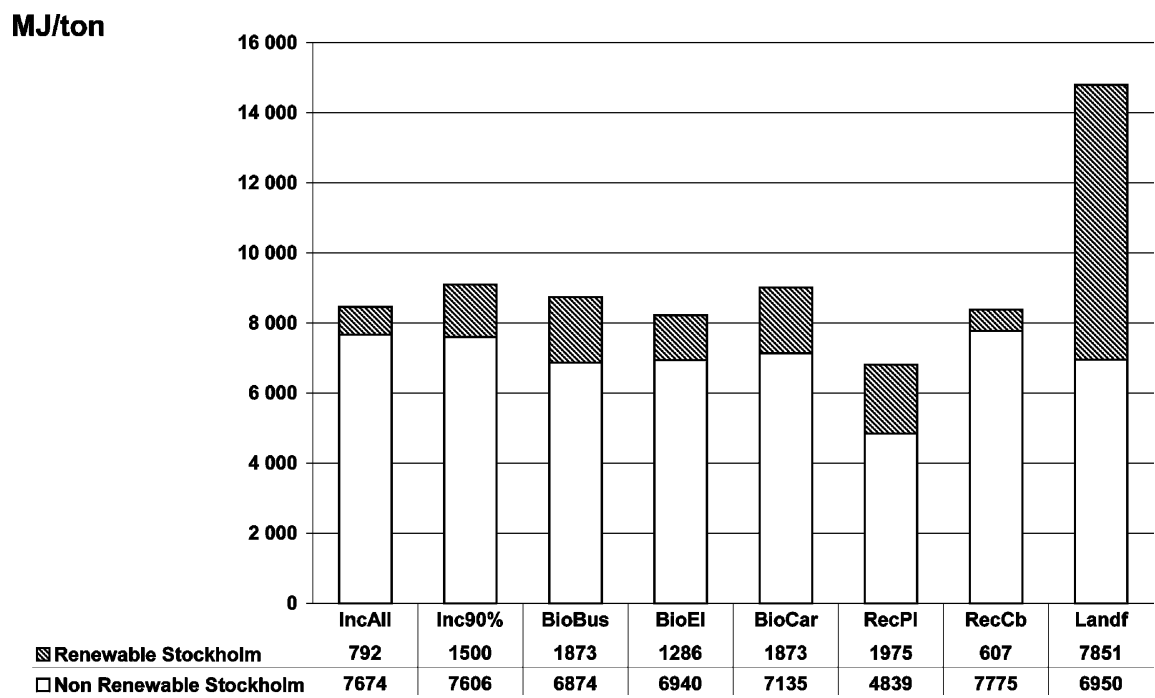

Fig. 6. Consumption of primary energy carriers for the different scenarios. 


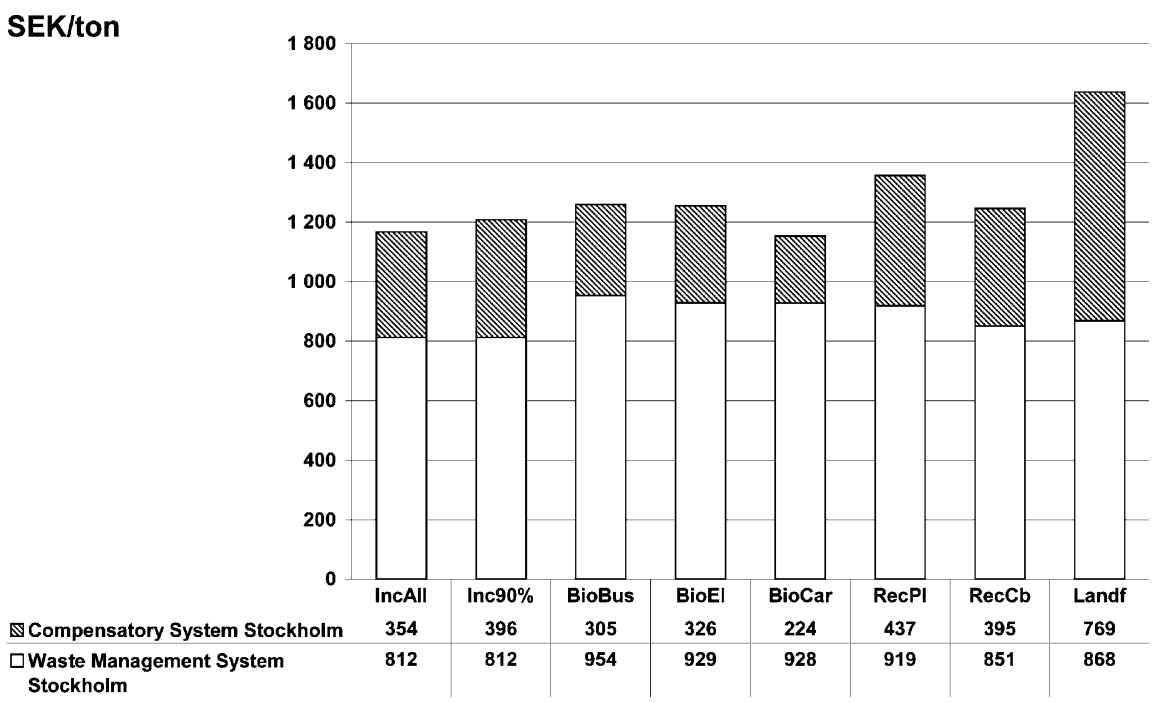

Fig. 7. Financial costs for the different scenarios.

cheaper, due to the high cost of gasoline, the alternative car fuel. In the waste management system, the dominant costs are for collection and incineration. Collection has a larger economic impact than environmental impact, although it does not vary substantially between scenarios. Incineration is costly as the majority of waste is incinerated in all scenarios except in the landfill scenario. For that scenario, landfill costs, including landfill tax, are naturally dominant.

From an economic point of view, incineration is more competitive than the recycling options, with the possible exception of anaerobic digestion of organic waste where the gas is used as car fuel.

The following waste fraction is worth source separating: none.

\subsection{Welfare costs}

The financial costs and the aggregated environmental costs are aggregated into welfare economic costs (Fig. 8). This aggregation is adjusted for environmental taxes (energy, carbon dioxide, and sulphur taxes on fuels, landfill tax) to avoid double accounting. The adjustments take place both in the waste management system and in the compensatory system, making a direct comparison between Figs. 7 and 8 impossible.

The overall cost level increases when environmental costs are included, although no major relative changes between the scenarios occur compared to the financial costs. Recycling of plastics and recycling of cardboard become somewhat more competitive compared to incin-

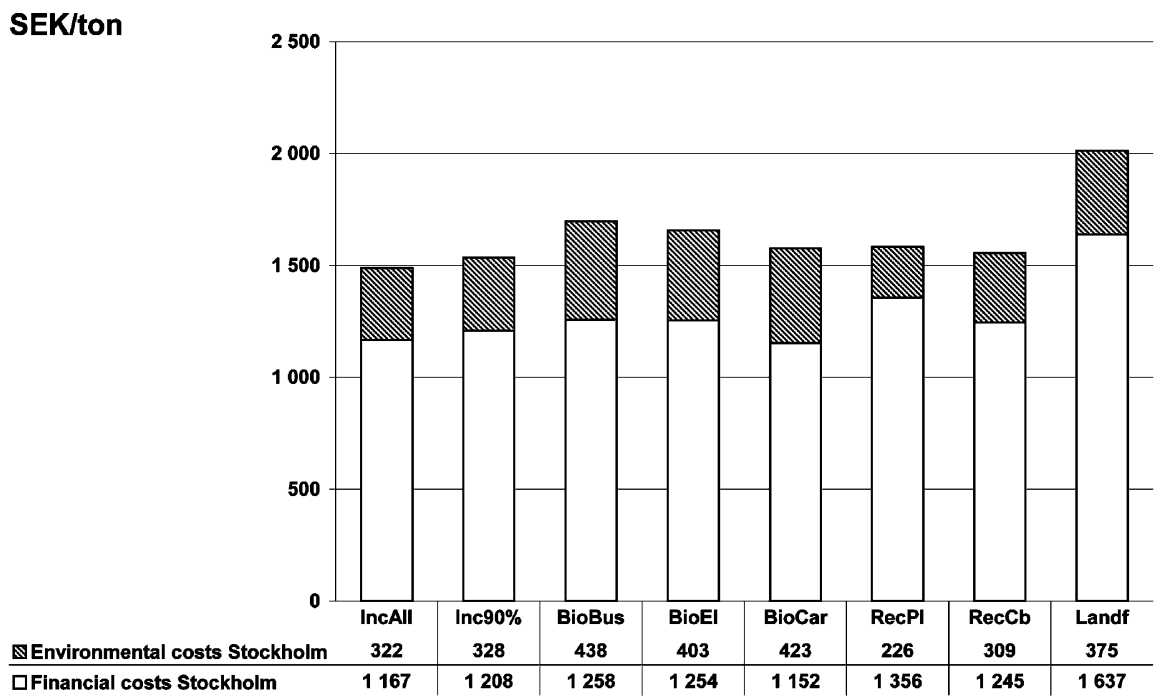

Fig. 8. Financial and environmental costs for the different scenarios. 
eration, but they are still slightly more expensive. Here, the BioCar scenario becomes more expensive than the Inc scenarios, so the slight cost advantage when comparing only the financial costs does not remain. The differences are very small, except for the landfilling scenario, which is still noticeably more expensive.

The following waste fraction is worth source separating: none.

\subsection{Other impact categories}

In the study, emissions of $\mathrm{NO}_{x}, \mathrm{VOC}$ and metals were also studied. Data for VOC and metals are not as well described as for other pollutants, so the results must be evaluated carefully. The result indicates that landfilling of household waste is the most polluting alternative.

For VOC, the lowest impact is found for recycling of plastic. The contribution from the compensatory system mainly emanates from vehicle fuel (mostly from petrol) and production of virgin plastic. This means that BioCar is lower than incineration. For all scenarios, except for the landfilling scenario, the compensatory processes emit more than the processes in the waste management system.

In terms of $\mathrm{NO}_{x}$-emissions BioBus, RecPl and $\mathrm{RecCb}$ are lower than incineration while landfilling and $\mathrm{BioEl}$ are higher. The highest emissions come from diesel engines which cause high emissions from the waste management system in scenarios BioBus, BioCar and Landf. In the compensatory system, diesel busses dominate the emission picture. Apart from BioBus, the contribution from the compensatory system is larger than from the waste management system.

For metals, the picture is not so sharp. Flows of lead, cadmium, mercury, copper, chrome, nickel and zinc were followed and a mass balance was set up. There are no big differences between the scenarios. The big sink for metals is in recycled materials (mostly metal containers) or in landfill after the surveyable time period. In all scenarios, almost the same amount of metals end up in the landfill, since most metals are found in the ashes and the slag from incineration. Ashes and slag are landfilled in each scenario. Biological treatment followed by spreading on arable land causes an increased emission of metals. These emissions are small compared to the total flow, but as the metals are exposed to living crops these small amounts become extremely vital.

\section{Differences between the studied municipalities}

There are major similarities in the results for the three case studies, even if there are major differences in the structure between the municipalities studied. The sce- narios for incineration and materials recycling show the same pattern in Stockholm as can be seen for Uppsala and Älvdalen. In Table 5, the results from the scenarios comparable between the municipalities are displayed.

In the case of Uppsala, composting of biodegradable waste is compared to anaerobic digestion and incineration. This was not performed in the case of Stockholm, as composting was not seen as a realistic alternative by the local waste planners. In the case of Uppsala, composting contributes more to GWP than anaerobic digestion, but lies within the same range as incineration. Regarding consumption of energy resources, acidification, and eutrophication, composting is less favourable than anaerobic digestion and incineration. The treatment cost for composting is lower than for digestion and incineration. But on the other hand, the cost contribution from the compensatory system is larger for composting than for anaerobic digestion. This system dynamics ends up in almost the same cost for the two alternatives. It should also be mentioned that there are some special wastes from companies in Uppsala that are treated by anaerobic digestion in each scenario (slaughterhouse waste, food industry waste, and nonhazardous pharmaceutical waste), despite the potential treatment of the household waste. However, these wastes do not affect the overall results, as all treatment facilities are considered to be run efficiently in all scenarios and all waste fractions carry their own impacts.

The large differences in the waste management system in Älvdalen, compared to the other two case municipalities, are an environmentally less sound landfill (no leachate water treatment and no gas collection) and a more inefficient waste collection (as Älvdalen is, as already mentioned, a sparsely populated municipality). The old-fashioned landfill in Älvdalen causes higher contribution to GWP, eutrophication, and thus also environmental costs. The low population intensity shows up in the results as higher costs for collection transports, and higher environmental impact and use of energy resources for waste collection. The increased transports (long distance transports to recycling facilities) lead to somewhat higher energy consumption and emissions, but the contribution to waste management costs from the collection dominate.

It was a common opinion among the waste managers in Älvdalen that it is hard to implement source separation of organic waste with a central treatment like anaerobic digestion or composting in the municipality. Therefore, a scenario comprising both central composting (for people living in city-like areas) and home composting (for households in rural areas) was studied besides the two scenarios for anaerobic digestion and central composting. However, as just $30 \%$ of the biodegradable waste was sorted out in the private households, no large differences could be seen except for a small decrease in collection transports. 
Table 5

Results for Uppsala and Älvdalen (units as in diagrams)

\begin{tabular}{|c|c|c|c|c|c|c|}
\hline Impact and area & IncAll & Inc $90 \%$ & BioBus & RecPl & $\mathrm{RecCb}$ & Landf \\
\hline GWP Uppsala WMS & 168 & 217 & 170 & 139 & 173 & 656 \\
\hline GWP Uppsala CS & 345 & 328 & 282 & 331 & 342 & 176 \\
\hline GWP Älvdalen WMS & 355 & 448 & 366 & 317 & 362 & 1307 \\
\hline GWP Älvdalen CS & 279 & 276 & 183 & 262 & 272 & 238 \\
\hline AP Uppsala WMS & 862 & 907 & 1358 & 858 & 860 & 1295 \\
\hline AP Uppsala CS & 2020 & 2024 & 1631 & 1944 & 1981 & 1699 \\
\hline AP Älvdalen WMS & 2800 & 2666 & 3479 & 2759 & 2783 & 1452 \\
\hline AP Älvdalen CS & 1786 & 1807 & 1152 & 1690 & 1724 & 1993 \\
\hline EP Uppsala WMS & 10 & 12 & 16 & 10 & 10 & 23 \\
\hline EP Uppsala CS & 9 & 10 & 6 & 9 & 9 & 11 \\
\hline EP Älvdalen WMS & 20 & 32 & 30 & 20 & 21 & 132 \\
\hline EP Älvdalen CS & 10 & 10 & 5 & 10 & 10 & 13 \\
\hline EnCon Uppsala Ren & 412 & 1259 & 1344 & 775 & 351 & 8874 \\
\hline EnCon Uppsala NonRen & 4346 & 4189 & 3632 & 3547 & 4358 & 2760 \\
\hline EnCon Älvdalen Ren & 345 & 1034 & 1379 & 1034 & 345 & 6897 \\
\hline EnCon Älvdalen NonRen & 4828 & 4828 & 3793 & 3793 & 4828 & 4483 \\
\hline FinC Uppsala WMS & 533 & 557 & 593 & 557 & 533 & 666 \\
\hline FinC Uppsala CS & 194 & 230 & 157 & 218 & 218 & 630 \\
\hline FinC Älvdalen WMS & 1555 & 1579 & 1897 & 1617 & 1641 & 1879 \\
\hline FinC Älvdalen CS & 141 & 179 & 59 & 166 & 162 & 534 \\
\hline WelC Uppsala Fin & 726 & 787 & 738 & 763 & 738 & 1283 \\
\hline WelC Uppsala Env & 230 & 254 & 412 & 206 & 230 & 484 \\
\hline WelC Älvdalen Fin & 1700 & 1762 & 1955 & 1783 & 1803 & 2414 \\
\hline WelC Älvdalen Env & 138 & 207 & 534 & 107 & 134 & 834 \\
\hline
\end{tabular}

GWP, global warming potential; AP, acidification potential; EP, eutrophication potential; EnCon, consumption of primary energy carriers; FinC, financial costs; WelC, welfare costs; WMS, waste management system; CS, compensatory system; Ren, renewable; NonRen, non-renewable; Fin, financial; Env, environmental.

\section{Discussion}

Despite the fact that the systems studied are designed with a high degree of source separation and well functioning facilities, the differences between energy recovery and materials and nutrients recycling are relatively small. This is explained by that, even with a high degree of source separation, a large part of the waste has to be incinerated. A marginal study [6], comparing differences between incineration and recycling of $1 \mathrm{~kg}$ of plastic, would show a greater difference. Our study covers the whole waste stream as the aim is to find the total impact for different changes in the treatment of specific fractions. It is however obvious that straight landfilling of mixed household waste is not a good waste treatment option.

The results show that there are benefits and drawbacks associated with all waste management options:

- A material recycling of plastic containers is comparable to incineration from an welfare economic point of view, but gives less environmental impact and lower energy use - on condition that the recycled plastic replaces virgin plastic. Recycling of plastic is the most expensive recycling option but results in the lowest impacts.

- A material recycling of cardboard containers is comparable to incineration for welfare economy and consumption of energy resources, but has both environmental advantages and disadvantages.

- Anaerobic digestion of easily degradable waste has a higher welfare economic cost than incineration, and has both environmental advantages and disadvantages. Conclusions regarding energy use depend upon how the biogas is used.

- Composting of biodegradable waste is comparable to anaerobic digestion from a welfare economic point of view, but gives higher energy use and environmental impact.

The study does not (with exception for the welfare economy) include a valuation of the importance of the different impact categories amongst themselves.

The overall conclusion from the study is that as long as landfilling is avoided, several waste treatments are possible and they are all better with respect to environmental impact, use of energy resources and economy. A combination of anaerobic digestion (with an improvement of the spreading technologies in the agricultural sector), materials recycling and incineration would probably be the best solution to avoid landfilling as much as possible. This conclusion holds true if the options are seen as being of almost equal merit in terms of costs and environmental impact, and having a redundant system (not to stick to only one method) is a wise thing. 
With respect to environment and consumption of energy resources, transports are of minor importance. In sparsely populated areas, collection and transports can be expensive, relatively speaking. In city areas, transports may affect human health comprising impacts as noise, etc. These impacts have not been evaluated in this study, due to difficulties in the assessment of ecotoxicology and impacts on human health.

\section{Further research}

Many of the results in this study are heavily dependent on assumptions for the design of the compensatory system and the scenarios. Further research can be directed at identifying and describing the influence on the results of the assumptions that have major importance for the main results. A broader discussion of the waste management from a social point of view may also be of interest. The effort needed from households differs between different waste management strategies, and this most certainly can have a major influence on the results.

\section{References}

[1] Council of European Union. Council Directive 1999/31/EC of 26 April 1999 on the landfill of waste. Official Journal of the European Communities 1999; L 182:1-19.

[2] European Parliament and the Council of the European Union. Directive 2000/76/EC of the European Parliament and of the Council of 4 December 2000 on the incineration of waste. Official Journal of the European Communities 2000;L 332:91-111.

[3] Naturvårdsverket. Har producenterna nått målen? Uppföljning av producentansvaret [in Swedish]. Report 5156, ISBN 91-6205156-3 Stockholm. Sweden: Swedish Environmental Protection Agency; 2001.

[4] RVF. Svensk Avfallshantering 2000 [in Swedish]. Annual booklet from the Swedish Association of Waste Management, Malmö, Sweden; 2001.

[5] Swedish Governmental Office. Skatt på avfall idag-och i framtiden [in Swedish]. Swedish Government Official Report SOU 2002:9. Stockholm, Sweden; 2002.

[6] Finnveden G, Johansson J, Lind P, Moberg A. Life cycle assessments of energy from solid waste. fms 137, FOA-B-00-00622-
222-SE. Report from Environmental Strategies Research Group, Stockholm, Sweden, 2000.

[7] Olofsson M. Energi från avfall. En integrerad studie av avfallshanterings- och energisystemet i Jönköping [in Swedish]. ISRN CTH-EST-R-01/1-SE, Division of Energy Systems Technology. Göteborg, Sweden: Chalmers; 2001.

[8] Cheng X, Jian-xin Y, Ru-song W. Life cycle assessment for municipal solid waste treatment and utilization. Journal of Environmental Sciences 2000;12(2):225-31.

[9] Beccali G, Cellura M, Mistretta M. Managing municipal solid waste. International Journal of Life Cycle Assessment 2001;6(4):243-9.

[10] Powell J. The potential for using life cycle inventory analysis in local authority waste management decision making. Journal of Environmental Planning and Management 2000;43(3):351.

[11] Aumonier S. The greenhouse gas consequences of waste management-identifying preferred options. Energy Conversion Management 1996;37(6-8):1117-22.

[12] Sundqvist J-O, Baky A, Björklund A, Carlsson Reich M, Eriksson $\mathrm{O}$, Frostell $\mathrm{B}$, et al. Systemanalys av energiutnyttjande från avfall-utvärdering av energi, miljö och ekonomi [in Swedish]. IVL reports B 1379, B 1380, B 1381, B 1382. Stockholm, Sweden: IVL Svenska Miljöinstitutet; 2000.

[13] Sonesson U. Systems analysis of waste management-the ORWARE model, transports and compost sub-models. PhD thesis, Agraria 130. Uppsala (Sweden): Swedish University of Agricultural Sciences; 1998.

[14] Björklund A. Environmental systems analysis of waste management-experiences from applications of the ORWARE model. PhD thesis TRITA-KET-IM 2000:15, ISSN 1402-7615, AFR report 303. Stockholm (Sweden): Royal Institute of Technology; 2000.

[15] Eriksson O. A systems perspective of waste and energy. Licentiate thesis TRITA-KET-IM 2000:16, ISSN 1402-7615. Stockholm (Sweden): Royal Institute of Technology; 2000.

[16] ISO. Environmental management-life cycle assessment-principles and framework. International standard ISO 14040. Geneva (Switzerland): International Organisation for Standardisation; 1997.

[17] Uppenberg S, Lindfors L-G. EPD: produktspecifika utgångspunkter för drivmedel [in Swedish]. SMS-Standard Report PSR: 1999:6. Stockholm, Sweden, 1999.

[18] Econ. Miljökostnader knyttet till ulike typer av avfall [in Norwegian]. Report 338/95, ISSN: 0803-5113, ISBN 82-7645-131-4. Oslo, Norway, 1995.

[19] Gren I-M. Alternative nitrogen reduction policies in the Mälar region, Sweden. Ecological Economies 1993;7:159-72.

[20] Otoma S, Mori Y, Terazono A, Aso T, Sameshima R. Estimation of energy recovery and reduction of $\mathrm{CO}_{2}$ emissions in municipal solid waste power generation. Resources, Conservation and Recycling 1997;20:95-117. 